\title{
How is the adequacy of micronutrient intake assessed across Europe? A systematic literature review
}

\author{
Garden Tabacchi ${ }^{1}$, Trudy M. A. Wijnhoven ${ }^{2}$, Francesco Branca ${ }^{3}$, Blanca Román-Viñas ${ }^{4}$, \\ Lourdes Ribas-Barba ${ }^{4}, \mathrm{Joy} \mathrm{Ngo}^{4}$, Alicia García-Álvarez ${ }^{4}$ and Lluís Serra-Majem ${ }^{4,5}$ \\ ${ }^{1}$ Institute of Physiology and Human Nutrition, University of Palermo, Palermo, Italy \\ ${ }^{2}$ Noncommunicable Diseases and Environment, World Health Organization Regional Office for Europe, Scherfigsvej 8 , DK-2100 \\ Copenhagen $\varnothing$, Denmark \\ ${ }^{3}$ Department of Nutrition for Health and Development, World Health Organization, Avenue Appia 20, CH-1211, Geneva 27, \\ Switzerland \\ ${ }^{4}$ Community Nutrition Research Centre of the Nutrition Research Foundation, University of Barcelona Science Park, Baldiri \\ Reixac 4, 08028 Barcelona, Spain \\ ${ }^{5}$ University of Las Palmas de Gran Canaria, PO Box 550, 35080 Las Palmas de Gran Canaria, Spain
}

(Received 7 January 2009 - Revised 23 April 2009 - Accepted 1 June 2009)

\begin{abstract}
EURopean micronutrient RECommendations Aligned is a network of excellence funded by the European commission, and established to address the problem of differences between countries in micronutrient recommendations as well as to understand how nutritional information including requirements and adequacy of intake is processed among different population groups. The aims of the present paper were to review the methods used for the adequacy assessment of the intake of six micronutrients of public health concern (vitamin $\mathrm{A}$, folate, vitamin $\mathrm{B}_{12}, \mathrm{Fe}, \mathrm{Zn}$ and iodine) in non-European and European nutrition surveys carried out on the apparently healthy population and to compare in particular the adequacy across surveys for folate intake. A systematic literature review was conducted to identify nutrition surveys that assessed micronutrient intake adequacy. The search yielded 9049 records, out of which 337 were eligible for the selected micronutrients. The majority (83.9\%) of the European surveys compared the adequacy of the nutrient intake against the Recommended Dietary Allowances (RDA); only a few surveys ( $8.0 \%)$ used the estimated average requirement cut-point method, while none of them used the probability approach. The comparison of folate inadequacy across eight countries revealed that about $25 \%$ of the adult female population had inadequate intakes when judged against the different recommendations used by the respective investigators, but nearly $75 \%$ had inadequate intakes when compared against the estimated average requirement cut-point value of $320 \mu \mathrm{g} / \mathrm{d}$. The present review showed that different methods were applied across Europe to estimate the adequacy of micronutrient intake, which led to different prevalence estimates of micronutrient inadequacy.
\end{abstract}

Dietary intake: Adequacy: Micronutrients: Folate: Adequacy assessment: Micronutrient intake

The dietary requirement for a micronutrient is defined as an intake level that meets specified criteria for adequacy, thereby minimising the risk of nutrient deficit or excess. These criteria cover a gradient of biological effects related to a range of nutrient intakes, which, at the extremes, include the intake required to prevent death associated with nutrient deficit or excess as well as other biological responses. The latter includes clinical disease as determined by signs and symptoms of nutrient deficiency, and subclinical conditions identified by specific biochemical and functional measures. Measures of nutrient stores or critical tissue pools may also be used to determine nutrient adequacy ${ }^{(1)}$.
One of the aims of nutritional assessment both at the individual and at the population level is to evaluate to what extent food and nutrient intake is 'adequate'. Ideally, the comparison between the requirement and the intake for every nutrient of interest for a certain individual or population should allow one to conclude whether the diet of that individual/population was adequate. As neither the real intake nor the real requirement for one individual is known, the evaluation of nutrient intake adequacy of an individual or population is based on the probability of adequacy. The calculation of the probability of adequacy is based on the assumption that intake is independent of requirement; although this assumption

Abbreviations: EAR, estimated average requirement; IOM, Institute of Medicine.

On behalf of EURRECA's RA 1.1 'Intake Methods' members: Serra-Majem L (Coordinator), Cavelaars A, Dhonukshe-Rutten R, Doreste JL, Frost-Andersen L, García-Álvarez A, Glibetic M, De Groot L, Henríquez-Sánchez P, Naska A, Ngo J, Novakovic R, Ortiz-Andrellucchi A, Øverby NC, Gurinovic M, Pijls L, Ranic M, Ribas-Barba L, Ristic-Medic D, Román-Viñas B, Ruprich J, Saavedra-Santana P, Sánchez-Villegas A, Tabacchi G, Tepsic J, Trichopoulou A, van't Veer P, Vucic V, Wijnhoven TMA.

* Corresponding author: Trudy M. A. Wijnhoven, fax +45391718 18, email twi@euro.who.int 
is not valid for energy intake, it is most likely applicable for vitamins and minerals ${ }^{(1,2)}$.

There are different statistical approaches that can be used to estimate the prevalence of adequate usual intakes from the distribution of intakes and requirements. The method used depends on the subject (individual or population), on the nutrient under study and the type of distribution of the intakes. These methods include the 'probability approach method' and the 'estimated average requirement (EAR) cut-point method'. The probability approach method requires the calculation of the probability of inadequacy of intake for each individual in a population subgroup, averaging the probabilities, and then using this average as an estimate of the prevalence of inadequacy. The EAR corresponds to the average daily nutrient intake level estimated to meet the requirement of half of the healthy individuals in a particular life stage and sex group. The EAR cut-point method is a short cut method of the probability approach and can be applied when the nutrient requirement is distributed symmetrically and the distribution of usual intakes is more variable than the distribution of requirements. If these conditions are met, the prevalence of inadequate intakes corresponds to the proportion of intakes that fall below the EAR. Other methods are the comparison to the cut-off values of the Recommended Dietary Allowances (RDA) or the comparison of the mean intake value of the population to the RDA, although they are inappropriate to define the population at risk of adequacy ${ }^{(1,3,4)}$. Other methods used are the scores of nutrient intake adequacy such as the nutrient adequacy ratio, which is calculated by dividing the estimated usual nutrient intake by the RDA, and the mean adequacy ratio, which is calculated by taking the sum of nutrient adequacy ratio of all micronutrients under study and then dividing it by the total number of nutrients. The percentage of the population with nutrient intakes below the Lowest Requirement Nutrient Intake is another calculation applied to estimate inadequacy.

EURopean micronutrient RECommendations Aligned is a network of excellence funded by the European commission, and established to identify and address the problem of differences between countries in micronutrient recommendations as well as to understand how nutritional information including requirements and adequacy of intake is processed among different population groups. The collected information will be used for the development of web-based computerised software to assess nutrient adequacy from dietary data collected in Europe. For its development, it will be necessary to have a clear framework of the methods being used to assess the micronutrient intake adequacy in Europe ${ }^{(5)}$.

To the authors' knowledge, a review of these methods has not been carried out yet. The aims of the present paper were to review the methods that have been used for the adequacy assessment of the intake of six micronutrients of public health concern - vitamin A, Fe, iodine, folate, vitamin $B_{12}$ and $\mathrm{Zn} \mathrm{-} \mathrm{in} \mathrm{non-European} \mathrm{and} \mathrm{European} \mathrm{nutrition} \mathrm{surveys}$ carried out on representative samples of an apparently healthy population. As an illustration, the estimated adequacy of folate intake found across surveys in adult women was compared.

Vitamin A deficiency, Fe deficiency anaemia and iodine deficiency disorders represent the three major micronutrients deficiencies in the world. Vitamin A deficiency is common in preschool-aged children throughout the world, but hardly any data were available in 1995 for the countries of the WHO
European Region $^{(6)}$. Anaemia currently affects $22 \%$ of the preschool-aged children and $25 \%$ of the pregnant women in the WHO European Region ${ }^{(7)}$. Insufficient iodine intake was found in 57 and $60 \%$ of the general population and schoolaged children, respectively ${ }^{(8)}$. While the global prevalence of folate deficiency is still uncertain, data suggest that low folate status is apparent among teenage girls in some European countries such as the United Kingdom (about $40 \%$ of $15-18$ year olds were found to have marginal folate status), and common among elderly people ${ }^{(9)}$. Furthermore, it is known that folate deficiency in women in childbearing age is associated with a higher risk of giving birth to infants with neural tube defects and other birth defects. A deficiency of folate in adults is in general associated with an increased risk of cardiovascular disease (CVD), cancer and impaired cognitive functions $^{(1)}$. In the United Kingdom $31 \%$ of the elderly and in Germany $15 \%$ of the women of reproductive age are reported to be vitamin $\mathrm{B}_{12}$ deficient $^{(9)}$. About $20 \%$ of the world's population is at risk of $\mathrm{Zn}$ deficiency ${ }^{(3)}$ and in Europe $\mathrm{Zn}$ intake among elderly is generally low ${ }^{(10)}$.

\section{Methods}

\section{Search strategy and eligibility criteria}

The present paper focuses on six micronutrients that represent public-health challenges and concerns ${ }^{(3)}$ : vitamin A, Fe, iodine, folate, vitamin $\mathrm{B}_{12}$ and $\mathrm{Zn}$. The search for surveys on the intake adequacy of micronutrients was carried out at the global level. European surveys included those conducted in one of the twenty-seven European Union countries (Austria, Belgium, Bulgaria, the Czech Republic, Cyprus, Denmark, Estonia, Finland, France, Germany, Greece, Hungary, Ireland, Italy, Latvia, Lithuania, Luxembourg, Malta, the Netherlands, Poland, Portugal, Romania, Slovakia, Slovenia, Spain, Sweden and the United Kingdom) or the four European Free Trade Association countries (Iceland, Liechtenstein, Norway and Switzerland).

A systematic literature search was performed in the PubMed database $^{(11)}$ (1990 to 30 March 2008; human studies only) on combinations of both medical subject headings and free-text keywords. It involved the use of each individual micronutrient key terms combined with searches about the concept of nutrient adequacy (e.g. (in)adequacy, (in)adequate intakes, threshold intake, cut point) and dietary intake (e.g. nutrition requirements, dietary intake, RDA). No language restrictions were applied at the search of studies in the PubMed database. Owing to limited translation possibilities, however, the final eligibility evaluation of full-text documents was restricted to publications in Dutch, English, French, German, Italian, Portuguese or Spanish only.

The first review stage involved the screening of titles, keywords and abstracts of the identified articles, to determine their appropriateness for inclusion. The reviewers were not blinded to the names of the authors, institutions or journal of publication. Observational (cross-sectional or cohort) studies carried out in apparently healthy population groups (children, adolescents, adults, elderly, pregnant and lactating women) and methodological papers on dietary intake and adequacy measurement were considered. Articles were excluded, when the information given in the title or available abstract 
suggested that the intake of micronutrients was not measured, the macronutrient intake adequacy was estimated only or that the survey was carried out in sick or institutionalised populations. Citations without an abstract or articles published in a language other than Dutch, English, French, German, Italian, Portuguese or Spanish were also excluded. The second screening stage involved the exclusion of articles, whose abstract did not provide descriptive information on the method used for the estimation of nutrient intake adequacy.

Surveys that fulfilled the first- and second-stage inclusion criteria were nevertheless excluded if they did not estimate the adequacy for any of the six selected micronutrients. The full text of the surveys identified to be potentially eligible was obtained and further evaluated during the last stage of the review. If more than one article was found for the same study, the article that provided the most relevant information was kept in the review.

\section{Data analysis}

All identified citations were downloaded into Reference Manager Version 10.0 $0^{(12)}$ and assigned a unique identification number and subsequently transferred into a database created with Microsoft Office Access $2003^{(13)}$, which was used for the screening and analysis. Extracted data were additionally entered into this database.
For each of the six micronutrients, the data of the surveys found eligible were tabulated by study design, population group and method used to assess intake adequacy. A distinction was made between the surveys that used the recommended methods as the EAR cut point or the probability approach method and the surveys that used the comparison against the cut-off value of the RDA. Other methods were also evaluated, such as the nutrient intake adequacy scores or the use of the percentage of the population with nutrient intakes below the lowest requirement nutrient intake.

For the comparison of the estimated folate intake adequacy across European surveys, the mean prevalence of folate inadequacy in European adult women was estimated with the use of the statistical software 'R', version 2.7.1 ${ }^{(14)}$. Surveys with information on mean folate intake and standard deviation were selected and the proportion of the population with an intake below the recommended national level was compared to the proportion of the population below the recommended EAR of $320 \mu \mathrm{g} / \mathrm{d}$, which is recommended by WHO and the $\mathrm{FAO}^{(1)}$.

\section{Results}

The search of the PubMed database yielded an initial 9049 records, out of which 8215 did not meet the first-stage inclusion criteria and were thus excluded from the review.

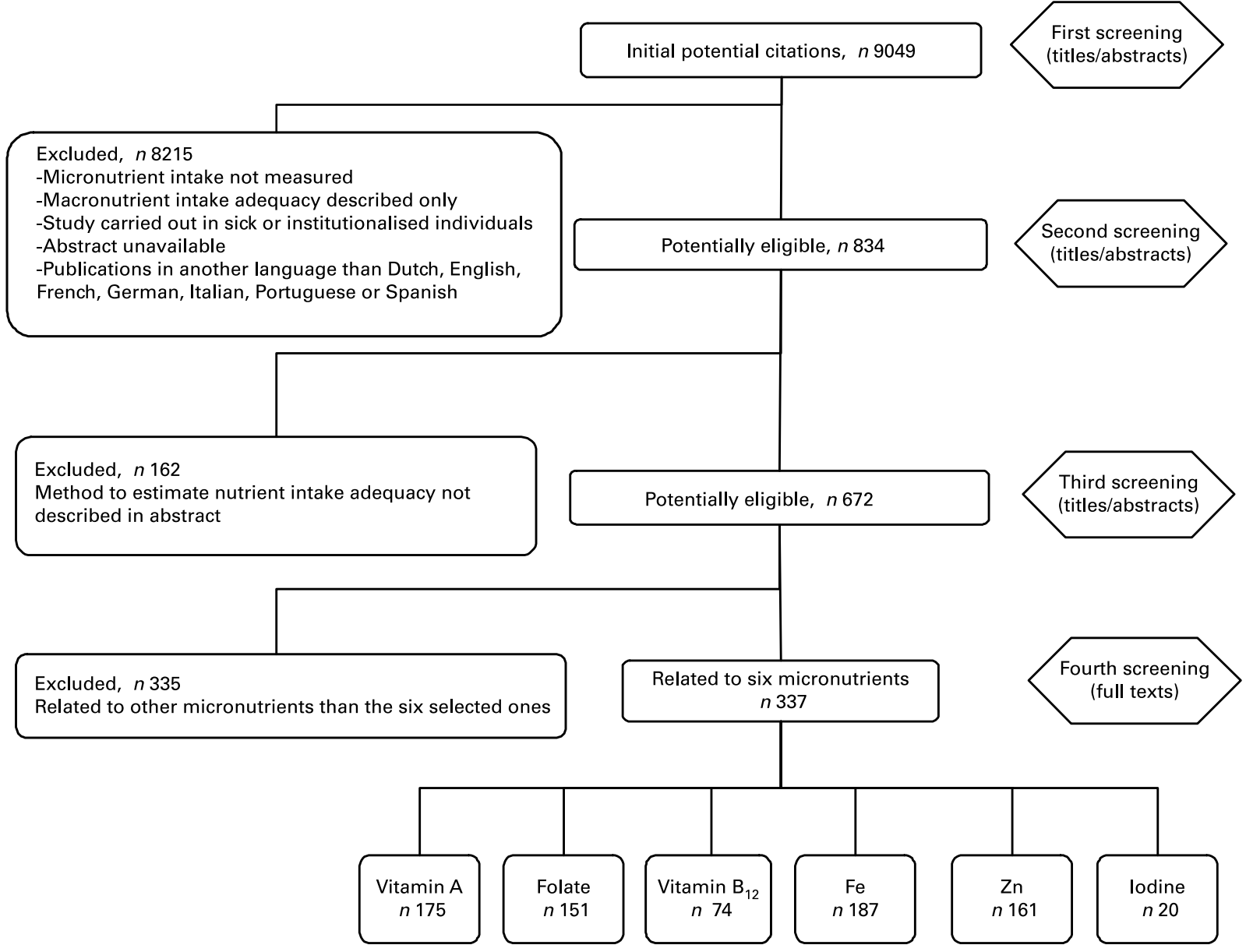

Fig. 1. Flow diagram of the process of identifying and including studies for the systematic literature review. 
Table 1. Number of articles, by micronutrient, study design and by location

\begin{tabular}{|c|c|c|c|c|c|c|c|}
\hline Micronutrient & $\begin{array}{l}\text { Total } \\
\text { number }\end{array}$ & $\begin{array}{l}\text { Methodological } \\
\text { reviews }\end{array}$ & $\begin{array}{l}\text { Reviews with } \\
\text { data }\end{array}$ & $\begin{array}{l}\text { Original } \\
\text { articles }\end{array}$ & $\begin{array}{l}\text { European } \\
\text { articles }\end{array}$ & $\begin{array}{l}\text { Non-European } \\
\text { articles }\end{array}$ & $\begin{array}{l}\text { Articles focusing on } \\
\text { only one micronutrient }\end{array}$ \\
\hline Vitamin A & 175 & 2 & 3 & 170 & 65 & 110 & 18 \\
\hline Folate & 151 & 3 & 3 & 145 & 56 & 95 & 19 \\
\hline Vitamin $B_{12}$ & 74 & 1 & 2 & 71 & 30 & 44 & 2 \\
\hline $\mathrm{Zn}$ & 161 & 7 & 4 & 150 & 49 & 112 & 20 \\
\hline lodine & 20 & 1 & 1 & 18 & 13 & 7 & 8 \\
\hline $\mathrm{Fe}$ & 187 & 3 & 3 & 181 & 71 & 116 & 18 \\
\hline $\begin{array}{l}\text { Total for six } \\
\text { micronutrients }\end{array}$ & 337 & 12 & 8 & 317 & 121 & 216 & \\
\hline
\end{tabular}

During the second and third screening phase, another 162 and 335 studies were excluded respectively, which resulted in a total of 337 articles included in the review that were related to the six selected micronutrients (Fig. 1). The full list of these references can be provided upon request.

\section{Global surveys}

Table 1 shows the number of articles included in the review for each micronutrient, and distinguishes reviews from original articles, European and non-European surveys, and studies that focus on only one micronutrient.

The majority of the studies targeted adults, followed by children, adolescents, elderly, pregnant/lactating women and infants (Table 2).

Results on the specific method used for the estimation of the adequacy of intake of the selected micronutrients are given in Table 3 . The main reference value used was the RDA, but some authors have also applied the EAR. The probability approach was used in five studies ${ }^{(15-21)}$. Some studies used other methods. For instance, four surveys applied the nutrient adequacy ratio and mean adequacy ratio $^{(22-25)}$ and three studies used the Lowest Requirement Nutrient Intake ${ }^{(26-28)}$. A study conducted in the United States on folate intake used the following other definition of 'adequacy': folate intake was defined as adequate when one consumed at least one folate-rich food at least 4-6 times/ week, and as 'inadequate' when one folate-high/rich/excellent food was consumed fewer than 2-3 times/week ${ }^{(29)}$.

\section{European surveys}

Out of the 121 European articles, nine methodological reviews were not considered in the present paper as they did not include original data, so that a total of 112 original articles were analysed.

The majority of studies $(83.9 \%)$ compared micronutrient intakes against the RDA for the estimation of adequacy. The probability approach method was never used. Only one study used another reference, the recommended values of the Caroline Walker Trust nutritional guidelines for primary schools ${ }^{(30)}$. Nine European studies $(8.0 \%)$ used the EAR/AR (average requirement) method, out of which two used it in combination with the RDA (Table 4); however, the EAR values applied differed across studies ${ }^{(40-48)}$.

\section{Adequacy of folate intake}

Eight European surveys were identified that estimated the prevalence of adequacy or 'inadequacy' of folate intake in European adult women and that provided a mean and SD intake (Table 5) ${ }^{(44,48-54)}$. Folate intake in Europe was inadequate in $25.1 \%$ of the adult female population, according to the comparison with the different recommendations used by the authors of the studies (Table 6). If the authors would have used the corresponding respective national recommendations, the percentage obtained would have been slightly higher (34.6\%); when using the national EAR as a reference, the proportion of the population having inadequate folate intake would have been $17 \cdot 1 \%$. Compared with the WHO/FAO recommendations of $400 \mu \mathrm{g} / \mathrm{d}$ and an EAR of $320 \mu \mathrm{g} / \mathrm{d}$, $92.1 \%$ and $74.8 \%$ of the adult female population would have an inadequate intake of folate, respectively.

\section{Discussion}

For the assessment of the adequacy of micronutrient intake in Europe, it is important to consider that the methods used for

Table 2. Number and percentages of articles targeting different age groups/pregnant and lactating women by micronutrient

\begin{tabular}{|c|c|c|c|c|c|c|c|c|c|c|c|c|}
\hline \multirow[b]{2}{*}{ Micronutrient } & \multicolumn{2}{|c|}{$\begin{array}{l}\text { Infants } \\
\text { (<1 year) }\end{array}$} & \multicolumn{2}{|c|}{$\begin{array}{c}\text { Children } \\
\text { (1-9 years) }\end{array}$} & \multicolumn{2}{|c|}{$\begin{array}{l}\text { Adolescents } \\
(10-19 \\
\text { years })\end{array}$} & \multicolumn{2}{|c|}{$\begin{array}{c}\text { Adults } \\
(>19 \text { years })\end{array}$} & \multicolumn{2}{|c|}{$\begin{array}{c}\text { Elderly } \\
\text { (>60 years) }\end{array}$} & \multicolumn{2}{|c|}{$\begin{array}{l}\text { Pregnant/ } \\
\text { lactating } \\
\text { women }\end{array}$} \\
\hline & $n$ & $\%$ & $n$ & $\%$ & $n$ & $\%$ & $n$ & $\%$ & $n$ & $\%$ & $n$ & $\%$ \\
\hline Vitamin A & 10 & $5 \cdot 7$ & 58 & $33 \cdot 1$ & 42 & $24 \cdot 0$ & 62 & $35 \cdot 4$ & 33 & $18 \cdot 9$ & 13 & $7 \cdot 4$ \\
\hline Folate & 4 & $2 \cdot 6$ & 29 & $19 \cdot 2$ & 32 & $21 \cdot 2$ & 54 & $35 \cdot 8$ & 28 & $18 \cdot 5$ & 15 & 9.9 \\
\hline Vitamin $B_{12}$ & 2 & $2 \cdot 7$ & 19 & $25 \cdot 7$ & 12 & $16 \cdot 2$ & 27 & 36.5 & 18 & $24 \cdot 3$ & 5 & $6 \cdot 8$ \\
\hline $\mathrm{Zn}$ & 15 & $9 \cdot 3$ & 29 & $18 \cdot 0$ & 26 & $16 \cdot 1$ & 42 & $26 \cdot 1$ & 27 & $16 \cdot 8$ & 15 & $9 \cdot 3$ \\
\hline lodine & 2 & $10 \cdot 0$ & 6 & $30 \cdot 0$ & 6 & $30 \cdot 0$ & 10 & $50 \cdot 0$ & 5 & $25 \cdot 0$ & 0 & 0.0 \\
\hline $\mathrm{Fe}$ & 14 & $7 \cdot 5$ & 54 & $28 \cdot 9$ & 47 & $25 \cdot 1$ & 54 & 28.9 & 31 & $16 \cdot 6$ & 17 & $9 \cdot 1$ \\
\hline Total for six micronutrients & 28 & 8.3 & 86 & $25 \cdot 5$ & 76 & 22.5 & 114 & 33.8 & 63 & $18 \cdot 7$ & 32 & 9.5 \\
\hline
\end{tabular}


Table 3. Number of articles indicating the reference used for estimating the intake adequacy, by micronutrient

\begin{tabular}{|c|c|c|c|c|c|c|c|c|c|c|c|c|}
\hline \multirow[b]{2}{*}{ Micronutrient } & \multicolumn{4}{|c|}{ RDA } & \multicolumn{3}{|c|}{ EAR } & \multicolumn{3}{|c|}{ Combination of RDA and EAR } & \multirow[b]{2}{*}{ Others } & \multirow[b]{2}{*}{ Total } \\
\hline & RDA & $\mathrm{RNI}$ & $\mathrm{RI}$ & $\mathrm{RDI}$ & EAR & AR & $\begin{array}{l}\text { Probability } \\
\text { approach }\end{array}$ & $\mathrm{RDA}+\mathrm{EAR}$ & $\mathrm{RNI}+\mathrm{EAR}$ & $\mathrm{RDI}+\mathrm{EAR}$ & & \\
\hline Vitamin A & 104 & 14 & 3 & 9 & 26 & 4 & 3 & 4 & 2 & 1 & 5 & 175 \\
\hline Folate & 81 & 17 & 3 & 5 & 30 & 4 & 2 & 2 & 2 & 0 & 5 & 151 \\
\hline Vitamin $B_{12}$ & 37 & 7 & 1 & 2 & 16 & 4 & 2 & 1 & 1 & 0 & 3 & 74 \\
\hline $\mathrm{Zn}$ & 88 & 14 & 4 & 1 & 35 & 4 & 5 & 3 & 1 & 0 & 6 & 161 \\
\hline lodine & 11 & 6 & 0 & 0 & 2 & 0 & 0 & 0 & 1 & 0 & 0 & 20 \\
\hline \multirow{2}{*}{$\begin{array}{l}\text { Fe } \\
\text { Total for six } \\
\text { micronutrients }\end{array}$} & 108 & 13 & 7 & 9 & 28 & 4 & 5 & 3 & 1 & 0 & 9 & 187 \\
\hline & \multicolumn{4}{|c|}{251} & \multicolumn{3}{|c|}{66} & & 9 & & 11 & 337 \\
\hline
\end{tabular}

RDA, Recommended Dietary Allowances; EAR, estimated average requirement; RNI, recommended nutrient intake; RI, recommended intake; RDI, recommended dietary intake; $A R$, average requirement.

data collection and analysis can vary throughout the different steps taken that lead to the estimation of adequacy. This can potentially result in an over- or underestimation of the usual intake and, as a consequence, of the adequate intake. The use of different methods for the collection of dietary intake data across surveys is an important source of variation in the estimate of micronutrient intake and thus in the estimate of micronutrient adequacy. In the second step, the food composition tables used to translate food intake into micronutrient intake might be another source of variation. Finally, the intake data analysed have to be compared against reference values. The main reference value used to assess adequacy was the RDA, both in non-European and in European studies. The latest dietary reference intakes published by the US Institute of Medicine (IOM) in $2000^{(4)}$ were accompanied with new suggestions about how the proposed updated references to nutritional assessment should be applied, including the application of nutritional requirements to assess nutrient intake adequacy. Despite that, from 2000 onwards, many studies (163 out of 199) still used the RDA value as a reference for estimating intake adequacy. Consequently, the use of this approach will lead to an overestimation of the prevalence of inadequacy compared to the use of the EAR cut-point value.

A few studies compared the intake with the mean group intake, assuming that if that value is approximate to the RDA, only $2-3 \%$ of the group members would have inadequate intakes. IOM does not recommend such an approach, as the RDA for a nutrient takes into account the individual variability of requirement and thus exceeds the requirement of almost all individuals. Comparing the mean intake of a group of individuals with the RDA underestimates the prevalence of individuals at risk of inadequate intake.

Table 4. Selected European studies that applied the EAR/AR reference values

\begin{tabular}{|c|c|c|c|c|c|c|c|c|}
\hline $\begin{array}{l}\text { Reference } \\
\text { value }\end{array}$ & $\begin{array}{l}\text { First } \\
\text { author }\end{array}$ & $\begin{array}{l}\text { Publication } \\
\text { years }\end{array}$ & $\begin{array}{l}\text { Survey } \\
\text { years }\end{array}$ & Country & $\begin{array}{l}\text { Population group } \\
\text { (age range) }\end{array}$ & $\begin{array}{l}\text { Sample } \\
\text { size }\end{array}$ & Sex & $\begin{array}{l}\text { Selected } \\
\text { micronutrients }\end{array}$ \\
\hline EAR $\left(\right.$ IOM $\left.2000^{(4)}\right)$ & Manios $^{(40)}$ & 2008 & $\begin{array}{r}2003- \\
2004\end{array}$ & Greece & $\begin{array}{l}\text { Infants, children } \\
(1-5 \text { years })\end{array}$ & 2374 & NA & Folate, $\mathrm{Fe}, \mathrm{Zn}$ \\
\hline $\begin{array}{l}\text { EAR and RNI } \\
\text { (United Kingdom } \\
\left.1991^{(31)}\right)\end{array}$ & Cowin ${ }^{(41)}$ & 2007 & 1994 & $\begin{array}{l}\text { United } \\
\text { Kingdom }\end{array}$ & $\begin{array}{l}\text { Children } \\
\quad \text { (18 months) }\end{array}$ & 1026 & NA & $\begin{array}{l}\text { Vitamin } \mathrm{A}, \\
\quad \text { folate, } \mathrm{Zn}, \\
\text { iodine, } \mathrm{Fe}\end{array}$ \\
\hline $\begin{array}{l}\text { EAR (United } \\
\text { Kingdom } 1991^{(31)} \\
\text { and United States } \\
\left.2001^{(32)}\right)\end{array}$ & Pynaert ${ }^{(42)}$ & 2007 & NA & Belgium & $\begin{array}{l}\text { Young adult } \\
\text { women (NA) }\end{array}$ & NA & NA & $\mathrm{Fe}$ \\
\hline $\begin{array}{l}\text { EAR (France } \\
\left.2001^{(33)}\right)\end{array}$ & Touvier ${ }^{(43)}$ & 2006 & 2000 & France & $\begin{array}{l}\text { Children, } \\
\text { adolescents, adults, } \\
\text { elderly (4-92 years) }\end{array}$ & 2373 & NA & $\begin{array}{l}\text { Vitamin } \mathrm{A}, \\
\quad \text { folate, } \mathrm{Fe}\end{array}$ \\
\hline $\begin{array}{l}\text { EAR (United States } \\
\text { IOM } 1997^{(34)} \\
\left.2002^{(35)}\right)\end{array}$ & Schroder ${ }^{(44)}$ & 2004 & $\begin{array}{r}1994- \\
1996\end{array}$ & Spain & $\begin{array}{l}\text { Elderly } \\
\quad(65-74 \text { years })\end{array}$ & 1748 & $\begin{array}{l}838 \mathrm{M}, \\
910 \mathrm{~F}\end{array}$ & $\begin{array}{l}\text { Vitamin } \mathrm{A}, \\
\text { folate, vitamin } \\
\mathrm{B}_{12}, \mathrm{Zn}, \mathrm{Fe}\end{array}$ \\
\hline $\begin{array}{l}\text { EAR (United } \\
\left.\quad \text { Kingdom } 1991^{(31)}\right)\end{array}$ & Emmett $^{(45)}$ & 2002 & 1996 & $\begin{array}{l}\text { United } \\
\text { Kingdom }\end{array}$ & $\begin{array}{l}\text { Children } \\
\quad(3 \text { years })\end{array}$ & 863 & NA & $\mathrm{Fe}$ \\
\hline $\begin{array}{l}\text { Basal requirement } \\
\text { (WHO/FAO/IAEA } \\
\left.1992^{(36)}\right)\end{array}$ & Michaelsen $^{(46)}$ & 1994 & $\begin{array}{r}1987- \\
1988\end{array}$ & Denmark & $\begin{array}{l}\text { Infants } \\
\quad(0-12 \text { months })\end{array}$ & 91 & NA & $\mathrm{Zn}$ \\
\hline AR $\left(\operatorname{EC~} 1993^{(37)}\right)$ & Kiely ${ }^{(47)}$ & 2001 & $\begin{array}{r}1997- \\
1999\end{array}$ & Ireland & $\begin{array}{l}\text { Adults } \\
\qquad(18-64 \text { years })\end{array}$ & 1379 & $\begin{array}{l}662 \mathrm{M} \\
717 \mathrm{~F}\end{array}$ & $\begin{array}{l}\text { vitamin } \mathrm{A} \text {, } \\
\quad \text { folate, vitamin } \\
\mathrm{B}_{12}, \mathrm{Fe}, \mathrm{Zn}\end{array}$ \\
\hline $\begin{array}{l}\text { EAR and RDA } \\
\text { (Dutch 1992- } \\
\left.1993^{(3839)}\right)\end{array}$ & Brussaard $^{(48)}$ & 1997 & NA & $\begin{array}{l}\text { The } \\
\text { Netherlands }\end{array}$ & $\begin{array}{l}\text { Adults, elderly } \\
\text { (20-79 years) }\end{array}$ & 444 & NA & Folate \\
\hline
\end{tabular}


Table 5. Selected European studies on inadequacy of folate intake in adult women

\begin{tabular}{|c|c|c|c|c|c|c|c|c|c|}
\hline First author & $\begin{array}{l}\text { Publication } \\
\text { year }\end{array}$ & $\begin{array}{l}\text { Survey } \\
\text { year }\end{array}$ & Country & $\begin{array}{l}\text { Reference value } \\
\text { for adequacy }\end{array}$ & $\begin{array}{l}\text { Cut-off } \\
\text { folate }(\mu \mathrm{g})\end{array}$ & $\begin{array}{c}\text { Population } \\
\text { inadequate (\%) }\end{array}$ & $\begin{array}{l}\text { Adult female } \\
\text { population }(n)\end{array}$ & $\begin{array}{l}\text { Mean } \\
\text { intake } \\
(\mu \mathrm{g})\end{array}$ & $\begin{array}{l}\text { SD } \\
(\mu g)\end{array}$ \\
\hline Hatzis ${ }^{(49)}$ & 2006 & NA & Greece & $\mathrm{RNI}\left(\mathrm{EC}^{(37)}\right)$ & 400 & $86 \cdot 5$ & 236 & 247 & 138 \\
\hline Sofi ${ }^{(50)}$ & 2005 & $2002-2003$ & Italy & $\operatorname{RDA}\left(\mathrm{IOM}^{(4)}\right)$ & 400 & 89.0 & 309 & 338 & 121 \\
\hline Planells ${ }^{(51)}$ & 2003 & NA & Spain & $\begin{array}{l}\text { RDA (Varela }{ }^{(55)} \\
\left.\text { and } 1 O M^{(56)}\right)\end{array}$ & $2 / 3$ of 200 & $23 \cdot 5$ & 1715 & 196 & 105 \\
\hline Aranceta $^{(52)}$ & 2001 & $1990-1998$ & Spain & $\begin{array}{l}\text { RDI (Varela }{ }^{(55)} \\
\text { and } \mathrm{EC}^{(37)} \text { ) }\end{array}$ & $2 / 3$ of 200 & $10 \cdot 0$ & 5480 & 252 & 103 \\
\hline O'Brien ${ }^{(53)}$ & 2001 & 1997-1999 & Ireland & $\mathrm{AR}\left(E C^{(37)}\right)$ & 140 & 8.9 & 717 & 260 & 144 \\
\hline Schroder ${ }^{(44)}$ & 2004 & $1994-1996$ & Spain & $\begin{array}{l}\text { EAR (US } \\
\left.\qquad \operatorname{IOM}^{(34,35)}\right)\end{array}$ & 320 & $70 \cdot 0$ & 662 & 285 & 66 \\
\hline Rasmussen ${ }^{(54)}$ & 2000 & 1998 & Denmark & $\begin{array}{c}\text { RI (NNR } \\
\left.1996^{(57)}\right)\end{array}$ & 300 & $64 \cdot 8$ & 258 & 276 & 90 \\
\hline Brussaard $^{(48)}$ & 1997 & NA & $\begin{array}{l}\text { The } \\
\text { Netherlands }\end{array}$ & $\begin{array}{l}\text { EAR and RDA } \\
\text { (source not } \\
\text { provided) }\end{array}$ & 400 & $95 \cdot 0$ & 300 & 270 & 79 \\
\hline
\end{tabular}

RNI, recommended nutrient intake; RDA, Recommended Dietary Allowances; NA, not available; AR, average requirement; EAR, estimated AR; RI; recommended intake.

The EAR cut-point method was not frequently used. The probability approach method was only applied in seven nonEuropean surveys, while it was not used at all in Europe. Other methods such as nutrient adequacy ratio and mean adequacy ratio were used in very few non-European studies.

Among the surveys that used the RDA as a reference, a wide range of reference values was used in Europe to assess nutrient intake adequacy. This means that the estimation of adequacy can also differ between countries.

The present paper presented the folate intake in European adult women as an example to illustrate how the use of different methods can lead to different prevalence estimates of nutrient inadequacy. Most health authorities recommend a daily intake of $200 \mu \mathrm{g}$ dietary folate for women, while

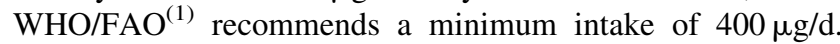
Few studies have shown that present dietary folate intake of adults in European countries meets the average RDA of $200 \mu \mathrm{g} / \mathrm{d}$, but not the recommended WHO/FAO value of $400 \mu \mathrm{g} / \mathrm{d}^{(58,59)}$. One study showed that weighed mean intake for women was $247 \mu \mathrm{g} / \mathrm{d}$ with a range of $168-320$, and median values lower than $200 \mathrm{mg} / \mathrm{d}$ were not frequently seen $^{(58)}$. As reported in another study, the dietary folate intake in eight European countries ranged from 207 to $284 \mu \mathrm{g} / \mathrm{d}$ for women and from 218 to $352 \mu \mathrm{g} / \mathrm{d}$ for men; for these European countries the average intake of dietary folate for men was 283 (SD 39) $\mu \mathrm{g} / \mathrm{d}$ and for women 238 (SD 26) $\mu \mathrm{g} / \mathrm{d}^{(59)}$.

The present results indicate that $25.1 \%$ of the European adult female population would have an inadequate folate intake according to the reference intake values that were considered in the respective surveys. Compared against the EAR, the prevalence of folate inadequacy turned out to be lower: in particular, the use of the corresponding national EAR cut-point values resulted in $17.1 \%$ of the population having inadequate intake of folate, whereas $74.8 \%$ were estimated to have inadequate folate intake when the $\mathrm{WHO} /$ FAO recommended EAR cut-point value of $320 \mu \mathrm{g} / \mathrm{d}$ was used as the reference. These calculations were made under the assumption that the intake of the population that was found to be inadequate in folate was normally distributed and therefore needs to be interpreted with caution. Furthermore, no correction for other factors was made. Nevertheless, the results give an indication of the variation that can occur when different methods are applied to estimate intake adequacy.

Table 6. Percentages of folate intake inadequacy in European adult women compared against different reference values

\begin{tabular}{|c|c|c|c|c|c|c|c|c|c|c|}
\hline \multirow{2}{*}{$\begin{array}{l}\text { Total adult } \\
\text { female } \\
\text { population } \\
(n)\end{array}$} & \multicolumn{2}{|c|}{$\begin{array}{l}\text { According to survey } \\
\text { results }\end{array}$} & \multicolumn{2}{|c|}{$\begin{array}{c}\text { Compared to national } \\
\text { RDA }\end{array}$} & \multicolumn{2}{|c|}{$\begin{array}{c}\text { Compared to national } \\
\text { EAR }\end{array}$} & \multicolumn{2}{|c|}{$\begin{array}{c}\text { Compared to WHO/ } \\
\text { FAO RNI }^{(1)}\end{array}$} & \multicolumn{2}{|c|}{$\begin{array}{l}\text { Compared to WHO/ } \\
\text { FAO EAR }^{(1)}\end{array}$} \\
\hline & $\begin{array}{l}\text { Population } \\
\text { inadequate } \\
(\%)\end{array}$ & $\begin{array}{l}\text { Cut-off } \\
\text { folate } \\
(\mu \mathrm{g})\end{array}$ & $\begin{array}{c}\text { Population } \\
\text { inadequate } \\
(\%)\end{array}$ & $\begin{array}{l}\text { Cut-off } \\
\text { folate } \\
(\mu \mathrm{g})\end{array}$ & $\begin{array}{l}\text { Population } \\
\text { inadequate } \\
(\%)\end{array}$ & $\begin{array}{l}\text { Cut-off } \\
\text { folate } \\
(\mu \mathrm{g})\end{array}$ & $\begin{array}{c}\text { Population } \\
\text { inadequate } \\
(\%)\end{array}$ & $\begin{array}{l}\text { Cut-off } \\
\text { folate } \\
(\mu \mathrm{g})\end{array}$ & $\begin{array}{c}\text { Population } \\
\text { inadequate } \\
(\%)\end{array}$ & $\begin{array}{l}\text { Cut-off } \\
\text { folate } \\
(\mu \mathrm{g})\end{array}$ \\
\hline 236 & $86 \cdot 5$ & 400 & $36 \cdot 7$ & 200 & 21.9 & 140 & $86 \cdot 5$ & 400 & $70 \cdot 2$ & 320 \\
\hline 309 & 89.0 & 400 & $12 \cdot 7$ & 200 & $5 \cdot 1$ & 140 & $89 \cdot 0$ & 400 & $44 \cdot 1$ & 320 \\
\hline 1715 & 23.5 & $2 / 3$ of 200 & 51.5 & 200 & $29 \cdot 7$ & 140 & $97 \cdot 4$ & 400 & $88 \cdot 1$ & 320 \\
\hline 5480 & $10 \cdot 0$ & $2 / 3$ of 200 & $30 \cdot 7$ & 200 & $13 \cdot 8$ & 140 & 92.5 & 400 & 74.5 & 320 \\
\hline 717 & 8.9 & 140 & $33 \cdot 8$ & 200 & $20 \cdot 2$ & 140 & 83.5 & 400 & $66 \cdot 2$ & 320 \\
\hline 662 & $70 \cdot 0$ & 320 & $9 \cdot 9$ & 200 & 1.4 & 140 & 95.9 & 400 & $70 \cdot 0$ & 320 \\
\hline 258 & $64 \cdot 8$ & 300 & 60.5 & 300 & 30.5 & 230 & 91.6 & 400 & $68 \cdot 8$ & 320 \\
\hline 300 & $95 \cdot 0$ & 400 & $64 \cdot 8$ & 300 & $30 \cdot 6$ & 230 & $95 \cdot 0$ & 400 & $73 \cdot 7$ & 320 \\
\hline 9677 & $25 \cdot 1$ & & 34.6 & & $17 \cdot 1$ & & $92 \cdot 1$ & & $74 \cdot 8$ & \\
\hline
\end{tabular}

RDA, Recommended Dietary Allowances; EAR, estimated average requirement; RNI, recommended nutrient intake. 


\section{Conclusions}

The present review showed that different methods have been applied across Europe to estimate the adequacy of micronutrient intake, which has led to different prevalence estimates of micronutrient inadequacy. The harmonisation of methods and the development of a software tool are important steps that can lead to a standardised way of estimating the adequacy of micronutrient intake in Europe. European micronutrient recommendations aligned has the potential to provide guidance to develop the proper tool that would enhance harmonisation of nutrient intake adequacy assessment across Europe.

\section{Acknowledgements}

This work was carried out within the framework of EURopean micronutrient RECommendations Aligned, a Network of Excellence, project No. FP6 036196-2, funded by the European Commission. The present report does not necessarily reflect the Commission's views or its future policy in this area.

G. T. screened the literature, undertook analysis and wrote the first draft of the paper. T. M. A. W. supervised the work, developed the literature search strategy, screened part of the literature and wrote the final draft of the paper. F. B. managed the project and commented on drafts of the paper.

B. R.-V. contributed to the literature search strategy and commented on drafts of the paper. L. R.-B. contributed to the design of the review and commented on drafts of the paper. J. N. contributed to the literature search strategy and commented on drafts of the paper. A. G.-A. contributed to the design of the review and commented on drafts of the paper. L. S.-M. contributed to the design of the review and commented on drafts of the paper.

There is no conflict of interest.

\section{References}

1. World Health Organization, Food and Agriculture Organization of the United Nations (2004) Vitamin and Mineral Requirements in Human Nutrition, 2nd ed. Geneva: World Health Organization and Rome/Food and Agriculture Organization of the United Nations, available at http://whqlibdoc.who.int/publications/ 2004/9241546123.pdf (accessed 30 November 2008).

2. Murphy SP \& Vorster HH (2007) Methods for using nutrient intake values (NIVs) to assess or plan nutrient intakes. Food Nutr Bull 28, Suppl. 1, S51-S60.

3. Allen L, de Benoist B, Dary O, et al. (editors) (2006) Guidelines on Food Fortification with Micronutrients. Geneva: World Health Organization, Rome: Food and Agriculture Organization of the United Nations, available at http://www.who.int/entity/ nutrition/publications/micronutrients/guide_food_fortification micronutrients.pdf (accessed 30 November 2008).

4. Food and Nutrition Board, Institute of Medicine (2000) Dietary Reference Intakes: Applications in Dietary Assessment. Washington, DC: National Academy Press.

5. Ashwell M, Lambert JP, Alles MS, et al. (2008) How we will produce the evidence-based EURRECA toolkit to support nutrition and food policy. Eur J Nutr 47, Suppl. 1, 2-16.

6. World Health Organization (1995) Global Prevalence of Vitamin A Deficiency. Micronutrient Deficiency Information System Working Paper No. 2. Geneva: World Health Organization, available at http://www.who.int/nutrition/publications/vad_global_prevalence/ en/index.html (accessed 30 November 2008).
7. de Benoist B, McLean E, Egli I, et al. (editors) (2008) World Prevalence of Anaemia 1993-2005. WHO Global Database on Anaemiaavailable at http://whqlibdoc.who.int/publications/ 2008/9789241596657_eng.pdf (accessed 30 November 2008).

8. de Benoist B, Andersson M, Egli I, et al. (editors) (2004) Iodine Status Worldwide. WHO Global Database on Iodine Deficiency Geneva: World Health Organization, available at http://whqlib doc.who.int/publications/2004/9241592001_eng.pdf (accessed 30 November 2008).

9. McLean E, de Benoist B \& Allen LH (2008) Review of the magnitude of folate and vitamin $\mathrm{B}_{12}$ deficiencies worldwide. Food Nutr Bull 29, S38-S51.

10. Andriollo-Sanchez M, Hininger-Favier I \& Meunier N (2005) Zinc intake and status in middle-aged and older European subjects: The ZENITH Study. Eur J Clin Nutr 59, S37-S41.

11. PubMed (online database) (2008) Bethesda: U.S. National Library of Medicine and the National Institute of Health, available at http://www.ncbi.nlm.nih.gov/entrez/query.fcgi?DB = pubmed (accessed 30 November 2008).

12. Reference Manager Network Administrator's Guide Version 10 (2002) Berkeley, CA: ISI Researchsoft, Thomson Scientific, available at http://www.refman.com/support/docs/Rm10Admin Guide_P.PDF\#search $=\% 22$ reference $\% 20$ manager $\% 2010 \% 20$ network\%22 (accessed 30 November 2008)

13. Microsoft Office Access 2003. Microsoft Corporation, 1992-2003.

14. R Development Core Team (2005) R: A Language and Environment for Statistical Computing. Vienna: R Foundation for Statistical Computing, available at http://www.R-project.org (accessed 30 November 2008).

15. Alaofe H, Zee J \& Turgeon OH (2007) Dietary iron and iron deficiency anemia among adolescent girls from Benin. Rev Epidemiol Sante Publique 55, 87-96.

16. Nolan K, Schell LM, Stark AD, et al. (2002) Longitudinal study of energy and nutrient intakes for infants from low-income, urban families. Public Health Nutr 5, 405-412.

17. Cid-Ruzafa J, Caulfield LE, Barron Y, et al. (1999) Nutrient intakes and adequacy among an older population on the eastern shore of Maryland: The Salisbury Eye Evaluation. J Am Diet Assoc 99, 564-571.

18. Martinchik AN \& Baturin AK (1997) Probability analysis of the risk of inadequate intake of nutrients in Moscow schoolchildren. Vopr Pitan 5, 26-29.

19. Murphy SP, Calloway DH \& Beaton GH (1995) Schoolchildren have similar predicted prevalences of inadequate intakes as toddlers in village populations in Egypt, Kenya, and Mexico. Eur J Clin Nutr 49, 647-657.

20. Calloway DH, Murphy SP, Beaton GH, et al. (1993) Estimated vitamin intakes of toddlers: predicted prevalence of inadequacy in village populations in Egypt, Kenya, and Mexico. Am J Clin Nutr 58, 376-384.

21. Murphy SP, Beaton GH \& Calloway DH (1992) Estimated mineral intakes of toddlers: predicted prevalence of inadequacy in village populations in Egypt, Kenya, and Mexico. Am J Clin Nutr 58, 565-572.

22. Hoerr SL, Horodynski MA, Lee SY, et al. (2006) Predictors of nutritional adequacy in mother-toddler dyads from rural families with limited incomes. J Am Diet Assoc 106, 1766-1773.

23. Steyn NP, Nel JH, Nantel G, et al. (2006) Food variety and dietary diversity scores in children: are they good indicators of dietary adequacy? Public Health Nutr 9, 644-650.

24. Lopes AC, Caiaffa WT, Sichieri R, et al. (2005) Nutrient consumption by adults and seniors in a population-based study: The Bambui Project. Cad Saude Publica 21, 1201-1209.

25. Schuette LK, Song WO \& Hoerr SL (1996) Quantitative use of the Food Guide Pyramid to evaluate dietary intake of college students. J Am Diet Assoc 96, 453-457. 
26. Rees GA, Doyle W, Srivastava A, et al. (2005) The nutrient intakes of mothers of low birth weight babies - a comparison of ethnic groups in East London, UK. Matern Child Nutr 1, 91-99.

27. Eves A \& Gesch B (2003) Food provision and the nutritional implications of food choices made by young adult males, in a young offenders' institution. J Hum Nutr Diet 16, 167-179.

28. Lightowler HJ \& Davies GJ (2000) Micronutrient intakes in a group of UK vegans and the contribution of self-selected dietary supplements. J R Soc Health 120, 117-124.

29. Chacko MR, Anding R, Kozinetz CA, et al. (2003) Neural tube defects: knowledge and preconceptional prevention practices in minority young women. Pediatrics 112, 536-542.

30. Gatenby LA (2007) Nutritional content of school meals in Hull and the East Riding of Yorkshire: a comparison of two schools. J Hum Nutr Diet 20, 538-548.

31. Panel on DRVs of the Committee on Medical Aspects of Food Policy (COMA) (1991) Dietary Reference Values (DRVs) for Food Energy and Nutrients for the UK. London: Department of Health.

32. Otten JJ, Hellwig J \& Meyers LD (2006) Dietary Reference Intakes (DRI). The Essential Guide to Nutrient Requirements. Summarizing Reference Values on Micronutrients from Reports 1997, 1998, 2000, 2001. Washington, DC: National Academies Press.

33. Martin A (editor) (2001) The "Apports nutritionnels conseillés" (ANC) for the French Population. Paris: French Food Safety Agency (AFSSA).

34. Standing Committee on the Scientific Evaluation of Dietary Reference intakes, Food and Nutrition Board, Institute of Medicine (1997) Dietary Reference Intakes for Calcium, Phosphorus, Magnesium, Vitamin D, and Fluoride. Washington, DC: National Academy Press, available at http://www.nap.edu/ catalog.php?record_id $=5776$ (accessed 5 December 2008).

35. Standing Committee on the Scientific Evaluation of Dietary Reference Intakes, Food and Nutrition Board, Institute of Medicine (2002) Dietary Reference Intakes for Vitamin A, Vitamin K, Arsenic, Boron, Chromium, Copper, Iodine, Manganese, Molybdenum, Nickel, Silicon, Vanadium, and Zinc. Washington, DC: National Academy Press.

36. World Health Organization, Food and Agriculture Organization of the United Nations, International Atomic Energy Agency (1996) Trace Elements in Human Nutrition and Health. Geneva: World Health Organization.

37. Commission of the European Communities (CEC) (1993) Nutrient and Energy Intakes for the European Community. Reports of the Scientific Committee for Food (Thirty-First Series) Luxembourg: Commission of the European Communities Directorate-General telecommunications, information, industries and innovation.

38. Voedingsraad (1992) Nederlandse Voedingsnormen 1989 (Dutch Recommendations for Intake of Nutrients). Advies opgesteld door de Commissie Voedingsnormen, Den Haag 13 juli 1989, 2nd ed. The Hague: Voorlichtingsbureau voor de Voeding, (in Dutch)

39. Gezondheidsraad/Voedingsraad (1993) Vervolgadvies inzake foliumzuurvoorziening in relatie tot neuraalbuisdefecten (Advice Concerning Folic Acid Intake in Respect of Neural Tube Defects). The Hague: Voorlichtingsbureau voor de Voeding, (in Dutch).

40. Manios Y, Grammatikaki E, Papoutsou S, et al. (2008) G. Nutrient intakes of toddlers and preschoolers in Greece: The GENESIS Study. J Am Diet Assoc 108, 357-361.
41. Cowin I \& Emmett P (2007) Diet in a group of 18-month-old children in South West England, and comparison with the results of a national survey. J Hum Nutr Diet 20, 254-267.

42. Pynaert I, Delanghe J, Temmerman M, et al. (2007) Iron intake in relation to diet and iron status of young adult women. Ann Nutr Metab 51, 172-181.

43. Touvier M, Lioret S, Vanrullen I, et al. (2006) Vitamin and mineral inadequacy in the French population: estimation and application for the optimization of food fortification. Int $J$ Vitam Nutr Res 76, 343-351.

44. Schroder H, Marrugat J, Covas M, et al. (2004) Population dietary habits and physical activity modification with age. Eur $J$ Clin Nutr 58, 302-311.

45. Emmett P, Rogers I \& Symes C (2002) Food and nutrient intakes of a population sample of 3-year-old children in the south west of England in 1996. Public Health Nutr 5, 55-64.

46. Michaelsen KF, Samuelson G, Graham TW, et al. (1994) Zinc intake, zinc status and growth in a longitudinal study of healthy Danish infants. Acta Paediatr 83, 1115-1121.

47. Kiely M, Flynn A, Harrington KE, et al. (2001) The efficacy and safety of nutritional supplement use in a representative sample of adults in the North/South Ireland Food Consumption Survey. Public Health Nutr 4, 1089-1097.

48. Brussaard JH, Lowik MR, van den Berg H, et al. (1997) Folate intake and status among adults in the Netherlands. Eur J Clin Nutr 51, Suppl. 3, S45-S50.

49. Hatzis CM, Bertsias GK, Linardakis M, et al. (2006) Dietary and other lifestyle correlates of serum folate concentrations in a healthy adult population in Crete, Greece: A Cross-sectional Study. Nutr $J \mathbf{5}, 5$.

50. Sofi F, Vecchio S, Giuliani G, et al. (2005) Dietary habits, lifestyle and cardiovascular risk factors in a clinically healthy Italian population: the 'Florence' diet is not Mediterranean. Eur J Clin Nutr 59, 584-591.

51. Planells E, Sanchez C, Montellano MA, et al. (2003) Vitamins $\mathrm{B}_{6}$ and $\mathrm{B}_{12}$ and folate status in an adult Mediterranean population. Eur J Clin Nutr 57, 777-785.

52. Aranceta J, Serra-Majem L, Perez-Rodrigo C, et al. (2001) Vitamins in Spanish food patterns: The Eve Study. Public Health Nutr 4, 1317-1323.

53. O'Brien MM, Kiely M, Harrington KE, et al. (2001) The North/ South Ireland Food Consumption Survey: vitamin intakes in 18-64-year-old adults. Public Health Nutr 4, 1069-1079.

54. Rasmussen LB, Ovesen L, Bulow I, et al. (2000) Folate intake, lifestyle factors, and homocysteine concentrations in younger and older women. Am J Clin Nutr 72, 1156-1163.

55. Varela G (1994) Tablas de ingestas recomendadas en energía y nutrientes para la población española. Madrid: Departamento de Bromatología, Universidad Complutense.

56. Food and Nutrition Board, Institute of Medicine (1998) Dietary Reference Intakes for Thiamin, Riboflavin, Niacin, Vitamin $B_{6}$, Folate, Vitamin $B_{12}$, Pantothenic acid, Biotin, and Choline. Washington, DC: National Academy Press.

57. Sandström B, Aro A, Becker W, et al. (1996) Nordiske Näringsrekommendationer 1996 (Nordic Nutrition Recommendations 1996). Copenhagen: Nordisk Ministerråd, Nordisk Forlagshus, Tema Nord, (in Swedish) pp. 28.

58. de Bree A, van Dusseldorp M, Brouwer IA, et al. (1997) Folate intake in Europe: recommended, actual and desiredintake. Eur $J$ Clin Nutr 51, 643-660.

59. Finglas PM (2005) FolateFuncHealth Project. Folate: From Food to Functionality and Optimal Health Norwich: Institute of Food Research, available at http://www.ifr.ac.uk/folate/ Final_Project_Report.pdf (accessed 17 December 2008). 